\title{
THE RELATIONSHIP BETWEEN UNIVERSITY STUDENTS' ATTITUDES TOWARDS ICT AND MEDIA TOOLS IN LEARNING ENGLISH AND THEIR EMOTIONAL INTELLIGENCE
}

\author{
Z. Zuhal Güven*
}

\begin{abstract}
This study aimed to investigate the relationship between the attitudes of university students towards using Information and Communication Technology (ICT) and media tools in learning English and their emotional intelligence. It also investigated whether the attitudes of university students towards using ICT and media tools in learning English and their emotional intelligence varied according to their gender and departments. The Turkish adaption of the revised Schutte emotional scale and The Attitude Scale for the Use of Media and ICT in Learning English were used as instruments to collect data in the study, which involved 143 female and 84 male, in total 227, university students. The independent $t$ test, one way analysis of variance and Pearson product moment correlation technique were used to analyze the data obtained related with the variables gender, departments and emotional intelligence respectively. A positive relationship between the attitudes of participants and emotional intelligence was found. The other finding was that the attitudes of university students towards ICT and media use in learning English varied significantly according to their gender and departments. It was recommended that more comprehensives studies be conducted with different and various working groups to develop new language programs from broader perspectives.
\end{abstract}

Key words: ICT and media tools, emotional intelligence, learning English

\section{ÜNIVERSITTE ÖĞRENCILERININ İNGILIZZCE ÖĞRENIMINDE BILLIŞIM TEKNOLOJISİ VE MEDYA ARAÇLARININ KULLANIMINA YÖNELIK TUTUMLARI İLE DUYGUSAL ZEKALARI ARASINDAKİ İLIŞKI}

$\mathrm{Bu}$ araştırmada üniversite öğrencilerinin İngilizce öğreniminde bilişim teknolojisi ve medya araçların kullanmaya yönelik tutumları ile duygusal zekâları arasındaki ilişki incelenmiştir. Araştırmada ayrıca üniversite öğrencilerinin İngilizce öğreniminde bilişim teknolojisi ve medya araçları kullanmaya yönelik tutumlarının ve duygusal zekalarının cinsiyet ve öğrenim gördükleri bölüm değişkenine göre farklılaşıp, farklılaşmadığ araştırılmıştır. Araştırmanın katılımciları 143'ü kız ve 84'ü erkek olmak üzere toplam 227 üniversite öğrencisidir. Veri toplama araçları olarak Schutte'nin Türkçeye uyarlanmış Duygusal Zekâ Ölçeği ile İngilizce Öğreniminde Medya ve Bilişim Teknolojisi Kullanımına Yönelik Tutum Ölçeği kullanılmıştır. Elde edilen veriler t testi, tek yönlü varyans analizi ve Pearson moment korelasyon tekniği ile analiz edilmiştir. Araştırma sonucunda üniversite öğrencilerinin İngilizce öğreniminde bilişim teknolojisi

*Yrd. Doç. Dr., Necmettin Erbakan Üniversitesi Sosyal ve Beşeri Bilimler Fakültesi 
ve medya araçların kullanmaya yönelik tutumları ile duygusal zekâları arasında pozitif yönde anlaml bir ilişki olduğu ve incelenen tutumlar ile duygusal zekalarmın cinsiyetleri ve bölümlerine göre anlaml şekilde farklılaştı̆̆g tespit edilmiştir. Yeni Yabancı Dil Ĕ̆itim Programlarmın geliştirilebilmesi için farkl ve çeşitli örneklem gruplarının dâhil edildiği daha kapsamlı araştırmaların yapılması tavsiye edilmiştir.

Anahtar Kelimeler: Bilişim teknolojisi ve medya araçları, duygusal zeka, Ingilizce öğrenimi

\section{INTRODUCTION}

Information and communication technology (ICT) and emotional intelligence (EI) are two important factors in determining how people learn languages. The rapid developments in ICT and the increasing interest in exploring emotions of human beings have brought about new insights into English Language Teaching (ELT). English language teaching has witnessed significant shifts in approaches, methods and materials in the last decades through the developments in ICT (Dudeney and Hockley 2012, Warschauer 1996). Easy and quick access to ICT systems and services has led to the construction of ICT-rich learning environment, which facilitates language learning. On the other hand, the role of emotions in language learning, which contributes greatly to positive learning environment, has been neglected, compared to the rational aspect of language learning, (Swain 2013). Given the assumption that ICT and media tools and emotional intelligence may play significant roles in foreign language learning, the study aimed to investigate the relationship between the participants' attitude towards ICT and media tools in learning English and their emotional intelligence. The facts that the number of people speaking English has risen dramatically in the last decades (Graddol 2000) and that English is the most the most commonly used language in the web (Internet World Stats 2015) while the report of Turkey in learning English is quite poor (Education First 2015, TEPAV 2013) were also the other motives to conduct the study.

Whether the attitudes of university students towards using ICT and media tools in learning English and their emotional intelligence varied according to their gender and departments was also investigated in this study. The literature review, method, results, discussion and recommendations are as follows.

\section{LITERATURE REVIEW}

\section{THE USE OF INFORMATION AND COMMUNICATION TECHNOLOGY IN ENGLISH LANGUAGE TEACHING}

Information and Communication Technology can be defined as the totality of the electronic tools, a mixture of hardware, software and communication facilities, 
The Relationship Between University Students'...

that are used to collect, store, present and distribute information to audience (Berce, Lanfranco and Vehovar 2008; Olatoye 2011). To Olatoye's definition (2011), it includes all related information and communication technologies such as media and broadcasting, telecommunications equipment and services, internet services provision, e-mails, voice-mails, cellular phones and electronic bulletin boards.

The history of ICT, which began with the installation of the first digital computer to do scientific calculation work in Kolkata in 1956, has witnessed remarkable transformation in various ways (Heeks 2008). The use of computing technology in governmental bodies in 1960s and 1970s was extended to encompass the business world in 1980s. With the advent of the Internet in the beginning of 1990s, the nature and scope of ICT has extended much beyond its initial use. Today information and communication technologies directly affect the way we access information, communicate with others and participate in social groups. The impact of ICT on individuals and societies has been researched from various aspects. While some studies point out that ICT has made life much easier and faster, particularly in communication, transportation, medication and education, some others indicate that it has caused many social problems such as alienation, loneliness and disconnection from real world (Davidow 2011; Kellner 2006, Khajehnoori 2010; Rainie and Wellman 2012). On the other hand, it is also put forward that the nature of socialization has changed due to the new technologies (Junco 2012; Lam 2012; Rouis et al. 2011; Van-Vooren and Bess 2013).

Considering the integration of ICT into learning environments, it can be said that many forms of ICT are used in the process, from computers and digital tools to information resources on the web, multimedia programs in CD-ROMs, and media and broadcasting organs, (Wang and Woo 2007). As for the practice, comprehensive studies on the impact of ICT use in education reveal that ICT has much to promise for the future of education (Cassen McNally and Vignoles 2015; Livingstone 2012).

The use of technology, particularly ICT and media tools, in learning English has been well-described in literature (Bax 2003, Dudeney and Hockley 2012, Warschauer 1996). The clear cut taxonomy by Dudeney and Hockley (2012) reveals how the nature and scope of learning English has been transformed since 1980s:

a) CALL (Computer Assisted Language Learning),

b) the great shift: Internet,

c) the future of technology: mobile learning. 
From a broader perspective, it could be said that these three stages represent the past, present and future of ICT in English Language Teaching (ELT). The journey of ICT, which started with computer assisted drill exercises and static texts through limited interactions between the learners and the content, headed towards more sophisticated and stimulating tasks with much emphasis on writing and critical thinking due to the advances in technology (Bax 2003; Warschauer 1996). The inclusion of multimedia and the arrival of the Internet led to a more integrated learning environment with enriched learning materials and better personal interactions, which promised a continuous process towards full ICT implementation (Bax 2003). With the increasing accessibility of the Internet, the ways of exploring, collecting and sharing knowledge and the nature of communication have changed dramatically, and they all have had implications in the ELT. English Language Teaching is closely related with human interaction and technology use. It has undergone significant changes due to the specific developments in information and communication technologies, and thus the learning environment, classroom practices, material types and the role of teachers have changed dramatically in the last three decades (Bax 2003; Dudeney and Hockley 2012; Warschauer 1996).

\section{EMOTIONAL INTELLIGENCE}

As language learning is a social process that requires communicative competence and collaborative working, emotional intelligence is of significant importance in ELT. In a positive learning environment, students are motivated, participatory, collaborative, creative and productive, which are traits closely related with emotional intelligence. In developing an ELT curriculum, emotional intelligence should be taken into consideration so as to meet the contemporary English Language Teaching standards through developing and implementing EI competencies (Tuncay 2002).

Emotional intelligence has been researched from various aspects in the last decades (Bar-On, 1997 and 2000; Boyatzis, Goleman and Rhee 2000; Goleman 1995, Goleman 1998; Mayer and Salovey 1997; Mayer Salovey and Caruso 2004; Salovey and Mayer 1990). Though there is a significant amount of work on emotional intelligence, it can be said that three theoretical approaches have guided the related research and publications so far: the EI ability model by Mayer and Salovey (1997), Emotional -Social Intelligence (ESI) Model by Bar-On (1997 and 2006), and Goleman's model of EI concentrated on emotional competencies (Goleman 1998).

While the origin of the concept of EI dates back to Gardner (1983), the systematic frame was constructed by Salovey and Mayer (1990:189), who defined emotional intelligence as "the ability to monitor one's own and others' feelings, to discriminate among them, and to use this information to guide one's thinking 
The Relationship Between University Students'...

and action". In another study, Mayer and Salovey (1997) redefined emotional intelligence as a set of skills that contribute to perceive, use, understand and manage emotions. In a more detailed study, Mayer and Salovey (1995) predicted that emotionally intelligent individuals are more likely to express emotions effectively, choose good emotional role models, convey and discuss feelings, and gain expert knowledge in a particular emotional area such as aesthetics, moral or ethical feeling, social problem solving, leadership, or spiritual feeling.

Soon after Salovey and Mayer's work in 1990, emotional intelligence took larger place in literature and a growing body of relevant research was conducted about it (Averill and Nunley 1992; Bar-On 1997; Cooper and Sawaf 1997; Goleman 1995; Mayer and Geher 1996; Stein Howard and Book 2011). In his popular book, Emotional Intelligence, Goleman (1995) extended the work of Salovey and Mayer (1990) by covering a great deal of multi perspective research on emotions and the brain, emotions and social behavior, and school-based programs designed to contribute to children's emotional and social development. He also made strong claims about emotional intelligence's contribution to individual and society by emphasizing the role of emotional intelligence in success at home, at school, and at work. Another important emotional intelligence theorist, Bar-On (1997: 3) combined mental abilities (e.g., emotional awareness) with other traits such as personal independence, adaptability skills, general mood, and stress management skills. Seeking an answer to the question why some individuals are more able to succeed in life than other, Bar-On tried to define emotional intelligence within the context of personality theory and described emotional intelligence as an array of interrelated emotional and social abilities and skills which enable people to know and manage emotions, to solve personal and interpersonal problems, and to cope with difficulties, challenges and pressures in daily life.

The studies into the role of Information and Communication Technology in English Language Teaching has been researched from various aspects (Baek 2008; Beatty 2003; Çapan 2012; Çuhadar and Yücel 2010; Demirbilek and Yücel 2011; Dudeney and Hockley 2012; Güneyli Birikim and Perkan 2009; Güven 2015; Murray 2000; Swain 2013; Warschauer 1996). Similarly, the relationship between emotional intelligence and ELT has aroused interest in academia (Esfandiari and Ekradi 2014; Mousapour and Khorrram 2015; Sucaromana 2012; Tuncay 2002; Tuyan and Sadik 2008). However, the literature review has not revealed any research that has investigated the relationship between emotional intelligence and the attitudes towards the use of ICT and media tools in ELT so far.

Considering the significance of these variables in learning English, the researcher aimed to investigate the university students' attitude towards ICT and media tools in learning English and their emotional intelligence to contribute to the area. The seemingly contrast between the emotional intelligence, which involves 
somewhat physical, personal and social contact between people, and the ICT and media tools, which are partly closed to physical contact with humans, also played role in the motivation of doing the research. The question as to whether the attitudes of the participants' attitudes towards the use of ICT and media tools and their emotional intelligence varied according to gender and department variable was the other motive in the research.

\section{METHOD}

The study examined whether the there is a relationship between emotional intelligence of university students and their attitude towards ICT and media tools in learning English. Relational screening model was used in the analysis of the data related with this variable. It also investigated whether the participants' attitudes towards ICT and media tools in learning English and their emotional intelligence varied according to their gender and departments. The independent $t$ test and one way analysis of variance were used to analyze the data related with the gender and the department variable respectively.

\section{Participants}

143 female and 84 male, in total 227, university students participated in the study in 2014-2015 academic year. The participants were the randomly selected out of the students in the Departments of Social Sciences, Art, Music and Mathematics at Ahmet Keleşoğlu Faculty of Education, Necmettin Erbakan University, in Konya/Turkey. The ages of the participants varied from 18 to 24 .

\section{Data Gathering Instruments}

The data about the attitudes of the participants towards using ICT and media tools in learning English were collected through the Attitude Scale for the Use of Media and ICT in Learning English (ASMICT), which the researcher had developed and tested in terms of validity and reliability before (Güven 2015). The scale was in the Likert-type, and had 16 questions and six responses with two endpoints ranging between "strongly agree" and "strongly disagree"

As for collecting data about the emotional intelligence of the participants, the Turkish adaption of the revised Schutte emotional scale, whose reliability and validity tests were done by Tartar et al. (2011), was used. The original scale was developed by Schutte et al. (1998), and revised by Austin et al. (2004). The revised version which was used in this study had 41 items with five responses ranging from "strongly agree" to "strongly disagree".

\section{Process}

The participants were selected randomly and asked to fill in the two scales and a personal information form. The data were analyzed with SPSS package program. 
The Relationship Between University Students'...

Pearson product moment correlation analysis, a quantitative research technique, was used to investigate whether there is a relationship between the emotional intelligence of university students and their attitude towards the ICT and media tools in learning English. Given the findings of the Tartar et al. (2011), total correlation was taken into consideration in interpreting the data. As the further step, whether the attitudes of university students towards using ICT and media tools in learning English and their emotional intelligence varied according to their gender and departments was investigated through $t$ test and one way analyses of variance.

\section{RESULTS}

The results obtained from the analyses of the data were given in the tables below:

Table 1. The Relationship Between The Participants' Emotional Intelligence (Ei) And Their Attitudes Towards The Use Of Media And Ict Tools In Learning English (Asmict)

EI

\begin{tabular}{|l|ll|}
\hline ASMICT & $\mathrm{r}$ & .303 \\
& $\mathrm{p}$ & $.000^{*}$ \\
& $\mathrm{n}$ & 227 \\
\hline
\end{tabular}

${ }^{*} \mathrm{p}<.01$

In Table 1, the relationship between ASMICT and EI was analyzed through Pearson product moment correlation technique. According to the results it was concluded that there was a .303 positive level relationship between the attitudes of the students towards using the media and ICT tools in learning English and their emotional intelligence $(\mathrm{r}=.30 ; \mathrm{p}<.01)$.

Table 1. The Investigation of ASMICT and EI Scores According to Gender Variable

\begin{tabular}{|c|c|c|c|c|c|c|}
\hline Dependent Variable & Gender & $\mathrm{n}$ & $\bar{X}$ & $\mathrm{Ss}$ & $\mathrm{t}$ & $\mathrm{p}$ \\
\hline \multirow{2}{*}{ ASMICT } & Female & 143 & 61.47 & 11.96 & \multirow{2}{*}{3.02} & .00 \\
\cline { 2 - 5 } & Male & 84 & 56.37 & 12.84 & & \\
\hline \multirow{2}{*}{ EI } & Female & 143 & 156.03 & 14.54 & 5.19 & .00 \\
\cline { 2 - 5 } & Male & 84 & 143.71 & 18.66 & & \\
\hline
\end{tabular}

Independent sampling $\mathrm{t}$ test was implemented to see whether the ASMICT and EI scores varied according to gender and the results were presented in Table 2. As is seen from the table, the means of female participants' scores from the ASMICT and EI are significantly higher than that of males (ASMICT: $t=3.02$; $p<.01$ and EI: $t=5.19 ; p<.01$ ). 
Table 3. The Investigation of ASMICT and EI Scores According to Department Variable

\begin{tabular}{|c|c|c|c|c|c|c|c|c|}
\hline $\begin{array}{l}\text { Dependent } \\
\text { Variable }\end{array}$ & & Department & $\mathrm{n}$ & $\bar{X}$ & Ss & $\mathrm{F}$ & $\mathrm{p}$ & $\begin{array}{l}\text { Significant } \\
\text { difference }\end{array}$ \\
\hline \multirow[t]{4}{*}{ ASMICT } & 1. & Social Sciences & 71 & 55.89 & 12.78 & \multirow[t]{4}{*}{5.66} & \multirow[t]{4}{*}{.00} & \multirow[t]{4}{*}{$1-3,1-4$} \\
\hline & 2. & Art & 61 & 58.00 & 13.94 & & & \\
\hline & 3. & Music & 40 & 62.75 & 8.69 & & & \\
\hline & 4. & Mathematics & 55 & 63.80 & 11.24 & & & \\
\hline \multirow[t]{4}{*}{ EI } & 1. & Social Sciences & 71 & 153.45 & 19.02 & \multirow[t]{4}{*}{2.79} & \multirow[t]{4}{*}{.04} & \multirow[t]{4}{*}{$2-3$} \\
\hline & 2. & Art & 61 & 146.10 & 16.68 & & & \\
\hline & 3. & Music & 40 & 153.93 & 18.48 & & & \\
\hline & 4. & Mathematics & 55 & 153.09 & 13.05 & & & \\
\hline
\end{tabular}

One way analysis of variance was applied to see whether the ASMICT and EI scores of the participants varied according to their departments. The results revealed that ASMICT scores of the participants varied significantly according to what department they were in $(\mathrm{p}<.01)$. As a result of the Scheffe test conducted to investigate the origin of this difference, it was found that the ASMICT scores of the participants in Social Sciences were significantly lower than those of the students in Music and Mathematics Education. As for EI, it was also found that emotional intelligence of the participants varied significantly according to their departments $(p<.01)$. The Scheffe test result revealed that the EI scores of Art Department students were significantly lower than those of the Music Department students.

\section{DISCUSSION}

With the introduction of information and communications technology and the media tools into language learning, how learners perceive these new shifts in learning English has been investigated comprehensively (Bax 2003; Cassen McNally and Vignoles 2015; Dudeney and Hockley 2012; Livingstone 2012; Warschauer 1996). On the other hand, the relationship between emotional intelligence and English language learning has attracted interest in the academia as well (Esfandiari and Ekradi 2014; Mousapour and Khorram 2015; Sucaromana 2012; Tuncay 2002; Tuyan and Sadik 2008; Zarafshan 2012). Given the assumption that emotional intelligence and technology may play significant roles in foreign language learning, the study aimed to investigate the relationship between the participants' attitude towards ICT and media tools in learning English and their emotional intelligence, and revealed that there is a positive relationship between them. The finding suggests that university students who are likely to adopt ICT and media tools in learning English are also likely to recognize their own and others' emotions. This may be because learning a language entails primarily intrapersonal and interpersonal communication and 
The Relationship Between University Students'...

interaction, which are the components of EI, and it also significantly benefits from sophisticated ICT and media tools as they facilitate and enrich learning English. Regarding the fact that ICT and media tools are the means of communication, it may seem plausible to anticipate a positive relationship between people's emotional intelligence and their attitude to ICT and media use in learning English.

Considering that emotional intelligence is strongly linked to social adaptability (Bar-On 1997), it may be argued that ICT and media tools might be used to improve communicative competence in learning English as they are means of communication. In the light of the literature on the changing nature of socialization due to new technologies (Junco 2012; Lam 2012; Rouis et al. 2012; Van-Vooren and Bess 2013; Wang and Woo 2007), it could be considered that people have positive attitude to getting into contact with the world through the ICT and media tools. The development of ICT use in ELT has covered a long way with significant changes that have facilitated communicative competence (Bax 2003; Cassen McNally and Vignoles 2015; Dudeney and Hockley 2012; Livingstone 2012; Warschauer 1996). As language learning is a part of human interaction and a means of communication, it requires knowing one's own emotions (self-awareness), managing them, motivating oneself, recognizing others' emotions and handling relationships with others properly, which are the five domains of emotional intelligence identified as self-management, motivation, self-regulation, empathy, and adeptness in relations (Goleman 1995). The finding of the study is supported with similar studies which have revealed that emotional intelligence is of significant effect in learning English (Esfandiari and Ekdradi 2014; Mousapour and Khorrram 2015; Sucaromana 2012; Tuncay 2002; Tuyan and Sadık 2008; Zarafshan 2012).

Another finding was that the means of female participants' scores from the ASMICT were significantly higher than that of males, which is supported by several studies that have revealed girls prefer to use ICT for learning and school work much more than boys do (Becta 2008; Ofcom 2008; Tekerek and Ercan 2012). There is also some other research that argue boys adopt more positive attitudes towards ICT and have better ICT skills (Sargin 2013; Varank 2007) The finding of the study is also significant as the international gender statistics community indicates the significance of gender and ICT in gender related issues (UNCTAD 2014). Considering the discernible rise in the awareness of the role of ICT in the empowerment of women, it is obvious that the participation of women in the information society could be realized through the acquisition of ICT skills (Bimber 2000, Kelka and Nathan 2002, Hilbert 2010, UNCTAD 2014). The finding of the study suggests that benefiting from computer- and/or Internet assisted education is in possibility for the female participants. 
It was also found that the means of female participants' scores from the emotional intelligence scale were significantly higher than that of males, which could be interpreted that female participants are more emotionally expressive than males. This finding is supported by similar studies which concluded that women have greater emotional knowledge, can express their emotions more fluently, recognize their own and others' emotions better and conduct more successful interpersonal relations than males (Erdoğdu 2008; Grewal and Salovey 2005; Grossman and Wood 1993; Harrod and Scheer 2005; Stein and Book 2011).

When the emotional intelligence of the participants was investigated in terms of the department variable, the means of the participants' scores in Art Department from Emotional Intelligence scale was found to be significantly lower than those in Music Department. This finding might be attributed to the social and interpersonal aspect of emotional intelligence. In another study conducted into the various faculty students (Erdoğmuş 2008), the emotional intelligence of Fine Arts students were found significantly higher than the students' in the Faculties of Law, Engineering, Letter and Physical Education. Due to the shortage of literature into the comparison of the departments, further studies seem to be necessary from larger perspectives.

The other finding was that the means of the participants' scores in Social Sciences Department obtained from ASMICT were significantly lower than the means of those in Music and Mathematics Departments. This finding is significant in the light of the long lasting claim since Pythagoras that there is a close connection between music theory and mathematics (Henle 1996; Papadopoulos 2002). Considering the view that music theory and music composition necessitate particular way of abstract thinking, which is very similar to mathematical pure thought (Papadopoulos 2002: 66), it could be argued that the students at Mathematics and Music Departments have similar interest in Information and Communication Technology. On the other hand, difference between the Social Sciences students' scores and those of Mathematics and Music departments might have resulted from the frequency and the way they use ICT and media tools in conducting classes and/or doing assignments. The differences between students' habits, interests and needs which are related with their departments might have played role in this difference as well.

The results obtained in this study are likely to shed light into the solution of the long lasting problems in English Language Teaching in Turkey. According to a recent report by Education First (2015) about the ranking of countries by their English levels, Turkey was listed as a country with a very low level English. Another comprehensive study into the needs assessment of English Language Teaching in Turkish state schools conducted by TEPAV (The Economic Policy Research Foundation of Turkey) and British Council (2013) revealed that 
students fail to learn how to learn English communicatively and functionally due to teacher-centric and classroom practice focused approach. What can be concluded from the report as to the cause of the problem is that Turkish learners are not adequately exposed to English to use it correctly and fluently. Owing to significant developments in technology which have transformed the classroom practices, material types, role of teachers and learning environment greatly in the last decades, ICT can offer rich and diverse prospects to both teachers and learners. Particularly through the widespread Internet use, people can access and share any kind of information easily, which is quite important to learn English (Bax 2003; Dudeney and Hockley 2012; Warschauer 1996). As far as the data by the Republic of Turkey Prime Ministry Investment Support and Promotion Agency (ISPACT), (2015), more than half of all households in Turkey have computers with internet access and this is expected to rise over 65.6 per cent in the five years, which indicates the interest in ICT in the country. Also, the data obtained from TUIK (Turkish Statistical Institute) (2015) reveals that the majority of the ICT users in Turkey are between 16 and 24 year-old, and the people with higher education level have the highest ratio among all the groups in using the ICT. Since the participants in the study were all university students, it could be inferred that ICT may contribute to the solution to the problems in ELT in Turkey by providing a new learning environment. Besides, considering the facts that the number of people speaking English has risen dramatically in the last decades (Graddol 2000) and that English is the most the most commonly used language in the web (Internet World Stats 2015), the findings of the study could be regarded as significant.

\section{RECOMMENDATIONS}

As the number and diversity of ICT users and applications increase day by day, similar studies should be carried out to investigate the relationship between emotional intelligence and the other forms of ICT usage that were not included in this study, like mobile devices. Also, similar scales could also be developed to assess the attitudes of ICT users in other ages and social groups.

New learning environments should be developed in accordance with the rapid developments in Information and Communication Technology. As English language is the target and the medium in learning English, language learners can be exposed to the target language as much as possible though the ICT enhanced learning environments. What should be born in mind is that emotional intelligence should be taken into consideration while developing new education plans based on ICT as it might also pose some risks such as the breakdown of group identity, the loss of normal relations, social isolation, violence, suicide and similar problems (Mitchell et al. 2005; Sargin 2012; Subrahmanyam et al. 2001) 
It should also be noted that the data gathering instrument used in this study to investigate the participants' attitudes towards ICT and media tools in learning English had an item about the role of e-mailing but it did not have any items related with social media platforms. Considering the increasing role of social media platforms like Facebook, Twitter, YouTube, Skype and blogs in society, it could be suggested that more comprehensive studies be conducted to investigate the topic from broader perspectives.

Due to the facts that the nature of ELT has become more and more technology driven in the last decades (Bax 2003; Dudeney and Hockley 2012; Warschauer 1996), and that language learning is a social process which requires emotional intelligence whose domains are self-management, motivation, self-regulation, empathy and adeptness in relations, (Goleman 1995), it could be recommended that new language programs be developed regarding the role of ICT and media tools and emotional intelligence in learning a foreign language.

\section{REFERENCES}

Austin E J, Saklofske D H, Huang S H and McKenney D (2004) Measurement Of Trait Emotional Intelligence: Testing And Cross-Validating A Modified Version of Schutte et al.'s (1998), Measure Personality and Individual Differences, 36(3), 555-562. DOI:10.1016/S0191-8869(03)00114-4

Averill J R and Nunley E P (1992) Voyages of the Heart: Living an Emotionally Creative, Free Press, New York.

Baek Y (2008) What Hinders Teachers in Using Computer and Video Games in the Classroom? Exploring Factors Inhibiting the Uptake of Computer and Video Games, Cyber, Psychology and Behavior, 11(6), 665-671.

Bar-On R (1997) Emotional Quotient Inventory: Technical Manual, Multi-Health Systems, Toronto.

Bar-On R (2000) Emotional and Social Intelligence: Insights from the Emotional Quotient Inventory, R. Bar-On \& J D Parker (Eds.), the Handbook of Emotional Intelligence, Jossey-Bass, San Franciso, 363-388.

Bar-On R (2006) The Bar-On Modelof Emotional-Social Intelligence (ESI), Psicothema, 18, supl, 13-25.

Bax S (2003) CALL- Past, Present and Future, System: An International Journal of Educational Technology and Applied Linguistics, 31(1), 13-28.

Beatty K (2003) Computers in the Language Classroom, D Nunan (ed), Practical English Language Teaching, Mc Graw Hill Publishing, Singapore, 247-266.

Becta (2008) How do Boys and Girls Differ in their Use of ICT? on February,2, 2016 retrieved from http://dera.ioe.ac.uk/8318/1/gender_ict_briefing.pdf 
The Relationship Between University Students'...

Berce J, Lanfranco S and Vehovar V (2008) E- Governance: Information and Communication Technology Knowledge Management and Learning Organisation Culture, Informatica, 32(2), 189-205.

Bimber B (2000) Measuring the Gender Gap on the Internet, Social Science Quarterly, 81(3), 868-876.

Boyatzis R, Goleman D and Rhee K (2000) Clustering Competence in Emotional Intelligence: Insights from the Emotional Competence Inventory (ECI), R. Bar-On and J D Parker (eds), Handbook of Emotional Intelligence, Jossey-Bass, San Franciso, 343-362

Cassen R, McNally S and Vignoles A (2015) Making a Difference in Education: What the Evidence Says, Taylor\&Francis Group /Routledge, , London, New York.

Cooper R K and Sawaf A (1997) Executive EQ Emotional Intelligence in Leadership and Organiztons, The Berkley Publishing, New York.

Çapan S A (2012) Teacher Attitudes towards Computer Use in EFL Classrooms, Frontiers Language Teaching, 3, 248-254.

Çuhadar C and Yücel M (2010) Yabancı Dil Öğretmeni Adaylarının Bilgi ve İletişim Teknolojilerinin Öğretim Amaçlı Kullanımına Yönelik Öz-yeterlilik Algıları, Pamukkale Üniversitesi Eğitim Fakültesi Dergisi, 27, 199-210.

Davidow W H (2012) Overconnected: The Promise and Threat of the Internet, Delphinium Books, New York, California.

Demirbilek M and Yücel Z (2011) İngilizce Öğretmenlerinin Bilgisayarın Yabancı Dil Öğretim Ve Öğreniminde Kullanımı Hakkındaki Görüşleri Uludağ Üniveristesi Eğitim Fakültesi Dergisi, 24(1), 217-246.

Dudeney G and Hockly N (2012) ICT in ELT: How Did We Get Here and Where Are We Going?, ELT Journal, 64(4), 533-542.

EF (Education First) (2015) English Proficiency Index 2015 on January, 23, 2016 retrieved from http://www.ef.com.tr/epi/regions/europe/turkey/

Erdoğdu M Y (2008) Duygusal Zekanın Bazı Değişkenler Açısından İncelenmesi, Research on Emotional Quotient in Terms of Certain Variables, Elektronik Sosyal Bilimler Dergisi, 7, 23, 62- 76, on January,14, 2016 retrieved from http://C:/Users/ user/ Downloads/50000681405000087673-1-PB\%20(1).pdf

Esfandiari R and Ekdradi E (2014) Relationship between Iranian EFL Learners' Emotional Intelligence and their Performance on Cloze Test, Elsevier Science Direct Procedia-Social and Behavioral Sciences, 98, 435-444.

Gardner H (1983) Frames of Mind Basic Books, New York.

Goleman D (1995) Emotional Intelligence, Bantam Books, New York. 
Goleman D (1998) Working with Emotional Intelligence, Bantam Books, New York.

Graddol D (2000) The Future of English, The British Council, U.K.

Grewal D and Salovey P (2005) Feeling Smart: The Science of Emotional Intelligence, American Scientist, 93, 330-339.

Grossman M and Wood W (1993) Sex Differences in Intensity of Emotional Experience: A Social Role Interpretation, Journal of Personality and Social Psychology, 93(65), 1010-1022.

Güneyli A, Birikim Ö and Perkan C (2009) Computer Use in Foreign Language Teaching: A Case Study From North Cyprus, Eurasian Journal of Educational Research, 34, 37-54.

Güven Z Z (2015) The Use of ICT and Media Tools in Learning English: A Scale Development Study, International Journal of Languages' Education and Teaching, 3(2), 312-323.

Harrod N R and Scheer S D (2005) An Exploration of Adolescent Emotional Intelligence in Relation to Demographic Characteristics, Adolescence, 40 (159), 503-512.

Heeks R (2008) ICT4D 2.0: The Next Phase of Applying ICT for International Development, Computer, 41(6), 26-33.

Henle J (1996) Classical mathematics. Baroque Mathematics. Romantic Mathematics? Also Atonal, Nez Age, Minimalist and Punk Mathematics, the American Mathematical Monthly, 103 (1), 18-29.

Hilbert H (2010) Digital Gender Divide or Technologically Empowered Women in Developing Countries?, Women's Studies International Forum, 3(6), 479-489.

Internet World Stats (2015) Internet World Users by Language: Top Ten Languages, on December, 22, 2015 retrieved from http://www.internetworldstats. $\mathrm{com} / \mathrm{stats} 7 . \mathrm{htm}$

ISPACT (2015) ICT, the Republic of Turkey Prime Ministry Investment Support and Promotion Agency, on December, 21, 2015 retrieved from http://www.invest. gov.tr/en-US/sectors/Pages/ICT.aspx

Junco R (2012) The Relationship between Frequency of Facebook Use Participation in Facebook Activities, and Student Engagement, Computers \& Education, 58, 162-171.

Kelkar G and Nathan D (2002). Gender Relations and Technological Change in Asia, Current Sociology, 50(3), 427-441. 
The Relationship Between University Students'...

Kellner D (2005) New Technologies and Alienation: Some Critical Reflections, L Langman and D Kalekin-Fishman (Eds), The Evolution of Alienation Trauma Promise and Millenium, Rowman and Littlefield Publishers, Maryland, 47-68.

Khajehnoori B (2010) The Relationship between ICT's and Adolescents' Delinquencies Case Study: Students in Abadeh County, Journal of Applied Sociology, 39(3), 113-134.

Lam L (2012) Review of Use of Animation as a Supplementary Learning Material of Physiology Content in Four Academic Years, The Electronic Journal of ELearning, 10(4), 377-386.

Livingstone S (2012) Critical Reflections on the Benefits of ICT in Education, Oxford Review of Education, 38(1), 9-24.

Mayer J D and Geher G (1996) Emotional Intelligence and the Identification of Emotion, Intelligence, 22, 89-113.

Mayer J D and Salovey P (1995) Emotional Intelligence and the Construction and Regulation of Feelings, Applied \& Preventive Psychology, 4, 197-208.

Mayer J D and Salovey P (1997) What is Emotional Intelligence?, P Salovey and D J Sluyter (eds), Emotional Development and Emotional Intelligence, Basic Books, New York, 3-34.

Mayer J D, Salovey P and Caruso D (2004) Emotional Intelligence: Theory, Findings and Implications, Psychological Inquiry, 15, 197-215.

Mitchell K J, Becker-Blease K A and Finkelhor D (2005) Inventory of Problematic Encountered in Clinical Practice, Professional Psychology: Research and Practice, 36, 498-509.

Mousapour G and Khorram A (2015) The Relationship between Iranian EFL Teachers' Emotional Intelligence and Their Teaching Styles International Journal of Research Studies in Language Learning, 4(4), 3-14.

Murray D E (2000) Changing Technologies, Changing Literacy Communities,. Language Learning and Technology, 4(2), 43-58.

Ofcom (2008) Media Literacy Audit: Report on UK Children's Media Literacy, on 24 January 2016 retrieved from http://stakeholders.ofcom.org.uk/binaries/ research/media-literacy/media-lit-2010/ml_childrens08.pdf

Olatoye R (2011) Levels of Participation in ICT Training Programmes, Computer Anxiety and ICT Utilization among Selected Professionals, International Journal of Education and Communication Technology, 7(2), 15-26.

Papadopoulos A (2002) Mathematics and Music Theory: from Pythagoras to Rameau, the Mathematical Intelligencer, 24(1), 65-73. 
Rainie L and Wellman B (2012) Networked: The New Social Operating System, MIT Press, Cambridge, MA.

Rouis S, Limayem M and Salehi-Sangari E (2011) Impact of Facebook Usage on Students' Academic Achievement: Role of Self-Regulation and Trust, Electronic Journal of Research in Educational Psychology, 9(3), 961-994.

Salovey P and Mayer J D (1990) Emotional Intelligence, Imagination, Cognition and Personality, 9, 185-211.

Sargin N (2012) Internet Addiction among Adolescence, Educational Research and Review, 7(27), 613-618

Sargın N (2013) Üniversite Öğrencilerinin İnternete Yönelik Tutumları ve Problemli İnternet Kullanımları- Internet Attitudes and Problematic Internet Use of University Students, Turkish Journal of Education, 2(2), 44-53.

Schutte N S, Malouff J M, Hall L E, Haggerty D J, Cooper J T, Golden C J and Dornheim L (1998) Development and Validation of a Measure of Emotional Intelligence, Personality and Individual Differences, 25 (2), 167-177.

Stein S J and Book H E (2011) EQ Edge Emotional Intelligence and your Success, Jossey-Bass A Wiley Imprint, Canada.

Subrahmanyam K, Kraut R, Greenfield P M and Gross, E F (2001) New Forms of Electronic Media: The Impact of Interactive Games and the Internet on Cognition, Socialization, and Behavior, DL Singer and J.L. Singer (eds.), Handbook of Children and the Media, Thousand Oaks Sage Publications, California, 73-99.

Sucaromana U (2012) Contribution to Language Teaching and Learning: a Review of Emotional Intelligence, English Language Teaching, 5(9), 54-58, DOI:10.5539/elt.v5n9p54

Swain M (2013). The Inseparability of Cognition and Emotion in Second Language Learning, Language Teaching, 46, 195-207, DOI: 10.1017/ S0261444811000486

Tatar A, Tok S and Saltukoglu G (2011) Adaptation of the Revised Schutte Emotional Intelligence Scale into Turkish and Examination of its Psychometric Properties, Klinik Psikofarmakoloji Bülteni-Bulletin of Clinical Psychopharmacology, 21(4), 325-338, DOI: 10.5455/bcp.20110624015920

Tekekrek M and Ercan E (2012) Analysis of Teachers' Attitude towards Internet Use: Example of Chemistry Teachers, Creative Education, 3 (3), 296-303.

TEPAV and British Council (2013) Turkey National Needs Assessment of State School English Language Teaching, on 22, December 2015 retrieved from http://www.britishcouncil.org.tr/sites/default/files/turkey_national_needs_assess ment_of_state_school_english_language_teaching.pdf 
The Relationship Between University Students'...

TUIK (2015) TurkStat, Information and Communication Technology (ICT) Usage Survey in Households and Individuals, 2004-2015, on 11, February, 2016 retrieved from http://www.turkstat.gov.tr/PreTablo.do?alt_id=1028

Tuncay H (2002) Emotional Intelligence in ELT/EFL Curriculum, Journal of Istanbul Kültür University, 2, 21-34.

Tuyan S and Sadik S (2008) Hand in Hand with Emotions: A Social and Emotional Learning Program for EFL Students, Çukurova Üniversitesi, Sosyal Bilimler Enstitüsü Dergisi., 17(3), 389-398.

UNCTAD (2014) Measuring ICT and Gender: An Assessment (Report Prepared for the Partnership on Measuring ICT for Development), United Nations, New York and Geneva, on May, 2, 2015 retrieved from http://www.uis.unesco.org/ Communication/Documents/measuring-ict-and-gender.pdf

Van-Vooren C and Bess C (2013) Teacher Tweets Improve Achievement for Eighth Grade Science Students, Systemics, Cybernetics and Informatics, 11(1), 33-36.

Varank I (2007) Effectiveness of Quantitative Skills, Qualitative Skills, and Gender in Determining Computer Skills and Attitudes: A Casual Analysis, Clearing House: A Journal of Educational Strategies, 81 (2), 71-80.

Wang Q and Woo H L (2007) Systematic Planning for ICT Integration in Topic Learning, Educational Technology \& Society, 10(1), 148-156.

Warschauer M (1996) Comparing Face-to-Face and Electronic Communication in the Second Language Classroom, CALICO Journal, 13(2), 7-26.

Zarafshan M (2012) the Relationship between Emotional Intelligence, Language Learning Strategies and English Proficiency among Iranian EFL University Students, Journal of Educational and Instructional Studies in the World, 2(3), 105-114. 